\title{
IMPACT OF PROTECTED METHIONINE AND LYSINE ON BODY WEIGHTS DURING PREGNANCY, LACTATION PERIODS AND SOME INDICATORS OF PRODUCTIVITY AND QUALITY OF WOOL IN AWASSI EWES
}

\author{
H. W. Kasim ${ }^{1}$ \\ O. D. Mohammed \\ S. Y. Abdul-Rahman \\ Anim. Prod. Dept. College of Agric. \& Forestry, University of Mosul \\ dr.omaralmallah@uomosul.edu.iq
}

\begin{abstract}
To evaluate the effect of protected methionine and lysine in the weights of ewes, their lamb's and wool growth . This study was conducted for the period from 1/5/2018 until 1/5/2019 in Bayoubakht area $20 \mathrm{~km}$ north of Mosul, in a private farm, using 16 pregnant Awassi ewes with average body weight $49.07 \pm 0.85$ and aged 2-3 years. Ewes were divided into two groups, fed with a restricted amount of $1.5 \mathrm{~kg}$ per ewe daily of standard ration without supplement in a control group, or ration supplemented with protected methionine $2.5 \mathrm{~g}$ and lysine $2.5 \mathrm{~g}$ per ewe daily in PRML group. Results were revealed that feeding with protected amino acids had no significant effects in ewes body weight during stages of pregnancy and milk production, but led to a significant ( $\mathrm{p} \leq$ $0.05)$ increase in lambs weight in the second and third month after birth $(16.60$ and $18.42 \mathrm{~kg}$ ) and total weight gain $14.11 \mathrm{~kg}$ as compared with Control 12.90, $14.28 \mathrm{~kg}$ and $9.57 \mathrm{~kg}$ respectively, as well as significant $(\mathrm{p} \leq 0.05)$ increase was noted in wool fleece in PRML group $2.16 \mathrm{~kg}$ as compared with C ontrol group $1.89 \mathrm{~kg}$, also average wool tress length and fiber length was improved when ewes fed with protected methionine and lysine by a ratio of 24.02 and $21.99 \%$ respectively as compared with the control. In conclusion, supplementation of ewes ration with protected methionine and lysine during pregnancy and lactating stages improve the growth performance of lambs, wool production, and characteristics.
\end{abstract}

Keywords : protected amino acids, body weight, wool growth . Received : 10/4/2020, Accepted : 6/5/2020

\section{INTRODUCTION}

Providing ruminants with the appropriate needs of nutritional compounds especially energy and protein may not be easy with many influencing factors such as the availability of suitable feed materials, physiological state of the animals, quantity and type of production, and other factors. The amino acids that available for absorption in the small intestine from feed and microbial protein are sufficient for the animals growth, but they are limited to growth when the animals have a high growth rate in crossbreeding and young animals (Anonymous, 2006), this is due to the low efficiency(50-59\%) of using amino acids for growth or weight gain ranging from. In this case, the protein content

\footnotetext{
${ }^{1}$ The research is part of the Ph.D. thesis of the first author.
} 
in the feed should be increase preferably of rumen undegradable protein sources to provide the needs of essential amino acids but this increase in protein may be associated with increased energy need to achieve the balance between energy and protein and this may be one of the important reasons for the difference in previous studies responses to undegradable protein or amino acids supplementation (Badawy and Ramadan, 2018). Also, type of production may require special needs of amino acids that exceed than other tissues of the body such as wool which require for growth a high amount of cysteine, methionine, and tyrosine. This was very clear when we notice that cysteine reaches $10 \%$ in about $20-40 \%$ of wool fiber, and tyrosine reach 1-12\% in about $10 \%$ of wool fiber, so the needs of protein for wool growth is higher than energy and since the most of the feed used in ruminant feeding contain a proportion of cysteine ranges between 2-5\% (Reis , 1979 and Mac Rae et al, 1993), so that the addition of cysteine as a supplement to feed provide a significant increase in the growth of wool, also methionine may acts as a source of the formation of the amino acid cysteine through the metabolic pathway. The current study was carried out to evaluate the impact of ration supplementation with protected methionine and lysine on growth performance and wool production and characteristics of different physiological stages of pregnancy and lactation.

\section{MATERIAL AND METHODS}

This study was conducted in the Bayoubakht area north of Mosul, $20 \mathrm{~km}$ in a private farm, using 16 pregnant local Awassi ewes average body weight $(49.07 \pm 0.85)$ and aged 2-3 years. Ewes were divided into two groups and fed with restricted amount $1.5 \mathrm{~kg}$ per ewe daily of standard ration ( Table 1), as well as grazing for 4-6 hours daily on artificial pasture, ewes were fed in the first group without supplement (Control) while ewes in the second group were fed with supplement protected amino acids methionine $2.5 \mathrm{~g}$ and lysine $2.5 \mathrm{~g}$ per ewe daily throughout the study from 1/5/2018 until 1/5/2019 which included various physiological stages (pregnancy and lactation), body weights were measured at different periods, as well as the weights of the newborn lambs at birth until weaning. Also, at the beginning of the study period ewes were sheared, the weight of the wool fleeces were recorded and a samples of wool were taken from the loin region about $10 \mathrm{~cm}^{2}$ of the right side between the $11^{\text {th }}$ and $12^{\text {th }}$ ribs according to (Gifford , 1989 and Taddeo et al., 2000). wool samples were carefully weighed using sensitive scale, wash thoroughly with hot water 50-60 $\mathrm{C}^{0}$ using detergents for three minutes to remove dirt and dust, then washed thoroughly with water and left for 24 hours to dry, samples were washed again with gasoline for three minutes to remove the fatty materials and left to dry for 24 hours then weighed to calculate clean wool ratio, as well three tress of wool were taken randomly from each wool sample to measure their length using a ruler according to (Von bergen , 1963) fiber diameter was measured in the general company for textile industries laboratories using airflow method (Andrews et al., 1987), at the end of the study 1/5/2019, ewes were sheared again and samples were taken and analyzed using the previous 
methods .The results were analyzed statistically using the complete random design (Anonymous, 2001), differences treatment mean was determined Duncan's multiple range test (1955).

Table (1) Ingredient and chemical composition of standard ration.

\begin{tabular}{|l|c|l|c|}
\hline Ingredients & $\%$ & Chemical composition \% & 92.43 \\
\hline Barley grain & 70 & Dry matter & 93.65 \\
\hline wheat bran & 21 & Organic matter & 13.74 \\
\hline Wheat straw & 7 & Crud protein & 9.59 \\
\hline Urea & 1 & Crud fiber & 1.72 \\
\hline Salt & 0.5 & Ether extract & 2445 \\
\hline Limestone & 0.5 & Metabolizable energy kcal $/ \mathrm{kg}$ feed &
\end{tabular}

Chemical composition were estimated according (Anonymous 2002).

Metabolizable energy calculated from Alkhawaja et al (1978).

\section{RESULTS AND DISCUSSION}

Results in Table (2) revealed that there were no significant differences in the initial body weight (ewes weight at mating) between control $49.45 \mathrm{~kg}$ and PRML group $48.69 \mathrm{~kg}$, also a non-significant differences were noticed along the three stages of pregnancy till lambing time, the average ewes body weight at lambing was $54.78 \mathrm{~kg}$ for control and 55.28 for PRML group. Table (2) also showed that the addition of protected methionine and lysine to ewes ration help the ewe to maintain its weight relatively during lactation periods as compared with control, ewes in the control group lost $7.43 \mathrm{~kg}$ (13.5\%) of weight, while the ewes in PRML group lost only $3.14 \mathrm{~kg}(5.6 \%)$ along the lactation period from lambing till weaning of lambs. The addition of protected methionine and lysine in the second group may have been an appropriate source for the synthesis milk protein in mammary gland or glucose in the liver by gluconeogenesis especially during early stage of lactation, which led to decrease body tissues mobilization for support the requirements of milk production and prevent lowering body weight as it in the control group (Oldham, 1994 ; Kim et al., 2001c), this result was agreed with Almallah et al (2018) in ewes and Almallah et al., (2018) in Shami goats, they found that feeding protected protein in late gestation had no significant effect in body weight, also (Obeidat et al 2008 , Flores et al., 2009 , Abdelrahman, 2013 and Al-Qaisi and Titi, 2014) they did not found significant improved in body weight as a result for the supplement protected methionine and lysine during lactation, but Lynch et al (1991) noted significant increase in body weight when crossbreed blackface ewes and their lambs fed with protected methionine and lysine .

Results in Table (3) showed that there is no significant differences in lambs weights at birth at the $1^{\text {st }}$ month of lactation period between the control group (4.30 kg and $10.02 \mathrm{~kg}$ ) and PRML treated group (4.36 kg and $11.83 \mathrm{~kg}$ ) respectively. The differences in lambs weights became evident with the progress of lactation period, so that lambs weights of PRML group was significantly $(p \leq 0.05)$ higher than lambs weight of control group at the end of 
$2^{\text {nd }}$ and $3^{\text {rd }}$ month of lactation $(16.60 \mathrm{~kg}$ and $18.42 \mathrm{~kg})$ as compared control group (12.90 kg and $14.28 \mathrm{~kg}$ ), as well as the total weights gain in PRML group $14.11 \mathrm{~kg}$ was significantly $(\mathrm{p} \leq 0.05)$ higher than control $9.57 \mathrm{~kg}$. the reason for this increase in lambs weights may not related to milk yield of ewes because it was close in the two groups 422 and $455 \mathrm{~g} /$ day respectively ( Kasim et al 2019) but may be due to the presence of lambs with their dams and fed with protected amino acids. It can be noted that methionine and lysine are considered to be amino acids specific for growth in growing lambs (Matras et al , 1999), this result may agree with Lynch et al., (1991) they found significant improve in lambs fed with their dams with protected methionine and lysine, Flores et al., (2009) illustrated that feeding Sanin goat kids with protected methionine for 30 days had no significant also, Abdelrahman (2013) and AlQaisi and Titi (2014) noted that Shami goats kids weight were not affected significantly when fed with protected methionine a compared control.

In regard to wool growth result in the table (4) revealed that there is no significant differences in fleece weight and characteristics in control group at the beginning $1 / 5 / 2018$ and the end of the experiment $1 / 5 / 2019$, meanwhile there is a significant $(\mathrm{p} \leq 0.05)$ differences in the diameter if wool fiber at the end of experiment (31.22 micron) as compared with the beginning of the experiment (28.13 micron) at the PRML treated group. when we compared between the results of the control and PRML treated groups at the end of experiment (1/5/2019), the result of table (5) reveled that PRML treatment improve most of the wool characteristics and the improvement reached to the significant $(\mathrm{p} \leq 0.05)$ in fleece weight $(2.16 \mathrm{~kg})$ as compared control $(1.89 \mathrm{~kg})$. his results were consistent with the findings of (Reis, 1991, Stephenson et al. 1990, Goetzee et al. 1995 and Hynd et al., 2015) they indicated that methionine had an important role in improving wool production, Wyrostek et al., (2019) they indicated that the feeding merino ewes by adding zinc-methionine led to a significant improvement in the length of the wool tress and the diameter of the fiber, this is what also got by Ramadan et al., (2017) when they fed ewes with protected methionine, while the result was not consistent with the results obtained by Baldwin et al., (1995) they did not found significant effect for the addition protected methionine in wool growth and fiber length in Dorset ewes.

Table(2): Effect of protected methionine and lysine in ewes weight .

\begin{tabular}{|l|c|c|}
\hline \multicolumn{1}{|c|}{ parameters } & Control group & PRML group \\
\hline Initial weight kg & $49.45 \pm 1.05$ & $48.69 \pm 1.41$ \\
\hline weight in early pregnancy kg & $54.71 \pm 1.69$ & $53.37 \pm 2.12$ \\
\hline weight in mid pregnancy kg & $59.28 \pm 1.58$ & $56.28 \pm 2.63$ \\
\hline weight in late pregnancy kg & $63.21 \pm 2.06$ & $64.42 \pm 3.37$ \\
\hline weight at lambing kg & $54.78 \pm 2.54$ & $55.28 \pm 1.77$ \\
\hline weight in early lactation kg & $48.42 \pm 2.40$ & $52.21 \pm 3.47$ \\
\hline weight in mid lactation kg & $49.14 \pm 2.08$ & $52.14 \pm 2.71$ \\
\hline weight in late lactation kg & $47.35 \pm 3.07$ & $52.14 \pm 2.84$ \\
\hline
\end{tabular}

Control group: ewes fed without supplement

PRML group : ewes fed with protected methionine and lysine 
Table (3): Effect of protected methionine and lysine in lambs weight.

\begin{tabular}{|l|c|c|}
\hline Parameters & Control group & PRML group \\
\hline Weight at lambing kg & $4.30 \pm 0.10$ & $4.36 \pm 0.42$ \\
\hline Weight in $1^{\text {st }}$ month kg & $10.02 \pm 0.80$ & $11.83 \pm 1.11$ \\
\hline Weight in $2^{\text {nd }}$ month kg & $12.90 \pm 1.29 \mathrm{~b}$ & $16.60 \pm 1.50 \mathrm{a}$ \\
\hline Weight in $3^{\text {rd }}$ month kg & $14.28 \pm 1.22 \mathrm{~b}$ & $18.42 \pm 1.47 \mathrm{a}$ \\
\hline Total gain kg & $9.57 \pm 1.21 \quad \mathrm{~b}$ & $14.11 \pm 1.27 \mathrm{a}$ \\
\hline
\end{tabular}

Control group: ewes fed without supplement

PRML group : ewes fed with protected methionine and lysine

Different letter in the same row differ significantly $(\mathrm{P} \leq 0.05)$.

Table(4): Effect of protected methionine and lysine in wool growth and characteristics in beginning and end experiment .

\begin{tabular}{|l|c|c|c|c|}
\hline \multirow{2}{*}{ Parameters } & \multicolumn{2}{|c|}{ Control group } & \multicolumn{2}{c|}{ PRML group } \\
\cline { 2 - 5 } & $1 / 5 / 2018$ & $1 / 5 / 2019$ & $1 / 5 / 2018$ & $1 / 5 / 2019$ \\
\hline Fleece weight kg & $1.84 \pm 0.06$ & $1.89 \pm 0.08$ & $1.93 \pm 0.20$ & $2.16 \pm 0.07$ \\
\hline $\begin{array}{l}\text { Length of wool } \\
\text { tress cm }\end{array}$ & $10.11 \pm 0.25$ & $9.24 \pm 0.61$ & $10.68 \pm 0.40$ & $11.46 \pm 2.49$ \\
\hline clean wool \% & $69.18 \pm 2.52$ & $76.68 \pm 4.08$ & $65.89 \pm 2.98$ & $75.18 \pm 2.13$ \\
\hline $\begin{array}{l}\text { Length of fiber } \\
\text { cm }\end{array}$ & $17.21 \pm 0.74$ & $15.32 \pm 1.02$ & $17.62 \pm 0.67$ & $18.69 \pm 3.94$ \\
\hline $\begin{array}{l}\text { Diameter of fiber } \\
\text { (micron) }\end{array}$ & $29.12 \pm 0.87$ & $31.05 \pm 0.98$ & $\begin{array}{c}28.13 \pm 0.71 \\
\mathrm{~b}\end{array}$ & $\begin{array}{c}31.22 \pm 1.05 \\
\mathrm{a}\end{array}$ \\
\hline
\end{tabular}

Control group: ewes fed without supplement

PRML group : ewes fed with protected methionine and lysine

Different letter in the same row differ significantly $(\mathrm{P} \leq 0.05)$.

Table (5): Effect of protected methionine and lysine in wool growth and characteristics.

\begin{tabular}{|l|c|c|}
\hline parameters & Control group & PRML group \\
\hline Fleece weight kg & $1.89 \pm 0.10 \mathrm{~b}$ & $2.16 \pm 0.07 \mathrm{a}$ \\
\hline Length of wool tress cm & $9.24 \pm 0.61$ & $11.46 \pm 2.49$ \\
\hline clean wool \% & $76.68 \pm 4.08$ & $75.18 \pm 2.13$ \\
\hline Length of fiber cm & $15.32 \pm 1.02$ & $18.69 \pm 3.94$ \\
\hline Diameter of fiber (micron) & $31.05 \pm 0.98$ & $31.22 \pm 1.05$ \\
\hline
\end{tabular}

Control group: ewes fed without supplement

PRML group : ewes fed with protected methionine and lysine

Different letter in the same row differ significantly $(\mathrm{P} \leq 0.05)$.

In conclusion, the RPML supplementation succeed in maintaining ewes weights during lactation period which require high levels of amino acids, also it help in weaning a heavier lambs, PRML treatment also improve the fleece weight and wool fiber diameter due to the important role of methionine as a source of for cysteine which is very important and critical for wool growth. 


\section{Acknowledgment:}

The authors would like to thanks the university of Mosul and college of agriculture and forestry for their kindly assistance to conduct the current research .

\section{تاثير الميثيونين واللايسين المحمي في اوزان النعاج خلال مرحلتي الحمل والرضاعة وبعض التوإ المؤشرات الانتاجية والنوعية للصوف في النعاج العواسية}

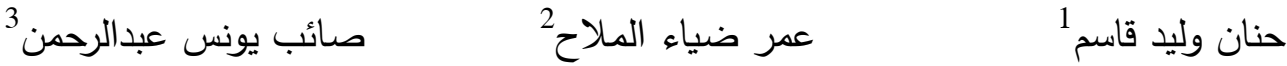

$$
\begin{aligned}
& \text { 1، } 2 \text { ، 3قسم الانتاج الحيواني ، كلية الزراعة والغابات ، جامعة الموصل ، العراق }
\end{aligned}
$$

\section{الخلاصة}

التقييم تأثير الميثيونين واللايسين الحميين في وزن النعاج والحملان ونمو الصوف ، أجريت هذه الدراسة للفترة من 2018/5/1 حتى 2019/5/1 في منطقة بايبوخت 20 كم شمال الموصل ، في مزرعة اهلية خاصة. باستخدام 16 نعجة حوامل متوسط وزن الجم 49.07 × 0.85 واعمارها تراوحت بين 2-3 سنوات. تم تقسيم النعاج إلى مجموعتين وتم تغذيتها بكمية محدودة من 1.5 كغم لكل نعجة يوميًا من العليقة القياسية بدون مكمل غذائي في مجموعة السيطرة ، أو بإضافة الميشيونين المحمي 2.5 غم ولايسين محمي 2.5 غم لكل نعجة في مجموعة الاحماض الامينية المحمية.

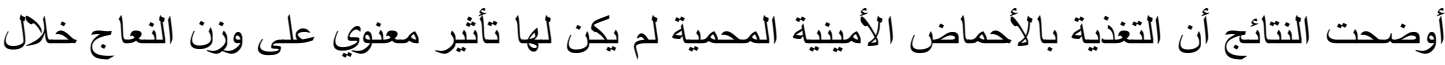

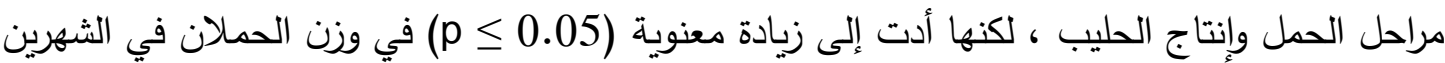

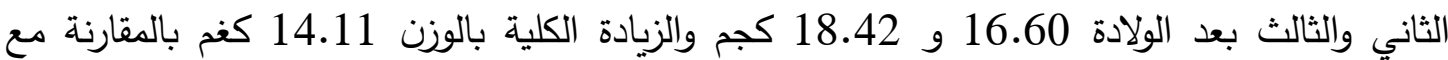

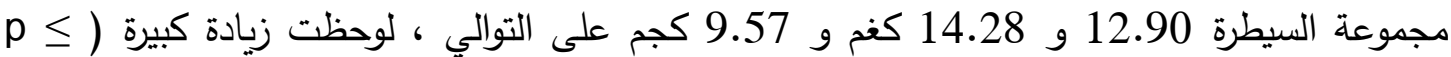
0.05) في وزن الصوف في مجموعة الاضافة بالحماض الامينية 2.16 كغم مقارنة مع مجموعة السيطرة 1.89 كجم ، كما تم تحسين متوسط طول خصلة الصوف وطول الألياف عند تغذية النعاج بالميثيونين واللايسين المحميين بنسبة 24.02 و 21.99٪ على التوالي مقارنة بمجموعة السيطرة. ،

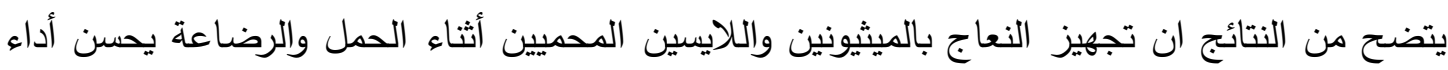
نمو الحملان وإنتاج الصوف وخصائصه.

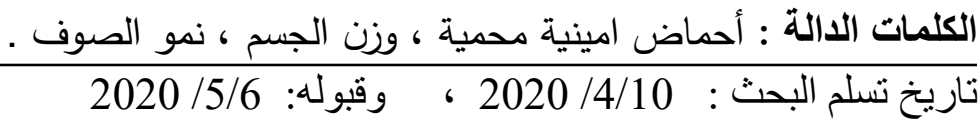

\section{REFERENCES}

Abdelrahman, M. M. (2013). Protein requirement of growing shami kids using protected methionine. Journal of Animal \& Plant Sciences . 17(1): $2425-2432$.

Al-Khawaja, A. K. Al-Bayati I. A. and Matti S. A (1978). Chemical Composition and Nutritional Value of Iraqi Feed Materials . $3^{\text {rd }}$ Edition. 
Ministry of Agriculture and Agrarian Reform, Directorate of Public Livestock, Iraq.

Almallah, O. D. ; M. N. Abdullah ; N. Y. Abbo and G. K. Khattab (2018a). Effect of formaldehyde treated barley on producing colostrum and milk and their components and some blood parameters in Damascus goats. Mesopotamia Journal of Agriculture. 46(2):148-156.

Almallah, O. D. ; M. N. Abdullah ; N. Y. Abbo and S. A. Tawfeeq (2018b). Effect of reducing barley grain degradability on lambs weight, colostrum's, milk production, their composition and some biochemical blood traits in Awassi ewes. Iraqi Journal of Veterinary Science $32(2): 15-22$.

Al-Qaisi, M. A. and H. H. Titi (2014). Effect of rumen protected methionine on production and composition of early lactating dairy goats milk and growth performance of their kids. Archive Tierzucht 57(1):1-14.

Andrews, R. N. ; H. Hawker and S. F. Crosbie ( 1987). Evaluation of five methods for measuring mean fiber diameter of fleece samples from New Zealand sheep . New Zealand Journal of experimental and Agriculture. 15: 23-31.

Anonymous , National Research Council (2006). Nutrient Requirements of Small Ruminants . Sheep, Goats, Cervids, and New World Camelids. The National Academies Press, Washington, DC, USA.

Anonymous, (2002). Official Method of Analysis. 17 ${ }^{\text {th }}$ Ed.( Association of Official Analytic Chemists), Washington, DC.

Anonymous. (2002). Statistical Analysis System. SAS Institute, Inc. Cary. NC.

Badawy, N. S. and W. A. Ramadan (2018). Studies in skin and wool fibers of Barki sheep fed on protected lysine and methionine. Research Journal of Animal and Veterinary Sciences. 10 (2): 28-37.

Baldwin, J. A. ; G. M. J. Horton ; J. E. Wholt ; D. D. Palatini ; S. M. Emanuele (1993). Rumen protected methionine for lactating, wool and growth in sheep . Small ruminant Research. 12:125-132.

Duncan CB (1955). Multiple Rang and Multiple "F” test. Biometric. 11:1-12.

Flores , A ; G. Mendoza ; J. Pinos-Rodriguez ; F. Plata ; S. Vega and R. Barcena (2009). Effect of rumen protected methionine on milk production of dairy goats. Italian Journal Animal Science 8:271-275.

Gifford, D. R. (1989). A note on the variation in fleece characteristics over the body of Australian angora bucks . Animal Production. 48:245-247.

Goetzee, J. P. J. Dewet and W. J. Burger (1995). Effect of infused methionine, lysine and rumen protected methionine derivatives on nitrogen retention and wool growth of merino weathers . South Africa Journal of Animal Science. 25(4):87-94.

Hynd, P. I. ; N. Edward ; S. Waver ; K. Chenoweth ; R. Storbat and N. Heberle (2015). Biological de fleecing : Intravenous infusion of amino acid mixture lacking lysine and methionine creates a weakened zone in the wool staple, which is amenable to mechanical wool harvesting . Animal Production Science. 55(10): 1264-1271. 
Kim, C. H. ; T. G. Kim ; J. J. Choung and D. G. Chamberlain (2001c). Effect of intravenous infusion of amino acids and glucose in the yield and concentration of milk in dairy cows. Journal of Dairy Research. 68: 2734.

Lynch, G. P. ; T. H. Elsasser ; C. Jackson ; T. S. Rumsey and M. J. Camp (1991). Nitrogen metabolism of lactating ewes fed rumen protected methionine and lysine. Journal of Dairy Science. 74:2268-2276.

Mac Rae, J. C. ; A. Walker ; D. Brown and G. E. Lobley (1993). Accretion of total protein and individual amino acids by organs and tissues of growth lambs and the ability of nitrogen balance technology to quantitate protein retention. Animal Production. 57: 237-245.

Matras, D. G. ; D. Mata and S. L. Liu (1999). The influence of type and timing of protein supplementation on wool growth and protein synthesis in the skin of young merino sheep. Australian journal Agriculture Research . 50: 497-502.

Obeidat, B. S. ; A. Y. Abdullah ; M. S. Awawdeh ; R. T. Tridi ; H. H. Titi and R. I. Qudsieh (2008). Effect of methionine supplementation on performance and carcass characteristics of awassi ram lambs fed finishing diets. Asian-Australian journal of Animal Science. 21(6): 831837.

Oldham, J. D. (1994). Amino acid nutrition of the dairy cow. In D'mello, J. P. F. (ed.). Amino acids in farm animal nutrition . CAB. International Wallingford pp. 351-375.

Kasim, H. W. ; O. D. Almallah and S. Y. Abdelrahman (2019). Impact of feeding protected methionine and lysine during different physiological periods in milk yield, composition, lamb growth and some blood biochemical traits of Awassi ewes. Mesopotamia Journal of Agriculture. 47(1):30-38.

Ramadan, W. A. ; M. A. El-Harairy ; W. A. Khalid and A.H. Youssef (2017). Impact of adding rumen protected lysine or (and) methionine on some wool characteristics in Barki sheep . Journal of Animal and Poultry Production. Mansura University. 8(7): 173-177.

Reis, P. J. (1979). Effects of amino acids on the growth and properties of wool In: Black, J. L. and Reis P. J. (eds) physiological and environmental limitation to wool growth . University of New England Publishing . Unit Armidale, Australia. pp. 223-242.

Reis, P. J. (1991). Nutritional regulation of wool growth in merino sheep. In : wool biology. Ed. Hynd, P. I. Australian Wool Corporation, Parkvill, Victoria. P 57.

Stephenson, R. G. ; G. R. Suter ; D. A. Pritchard and M. D. Martin. (1990). Studies of wool growth response to 2-hydroxy-4-(methylthio) butanoic acid, Alimet, an analogue of methionine. Australian journal experimental Agriculture. 30:477. 
Mesopotamia J. of Agric.

ISSN: 2224 - 9796 (Online)

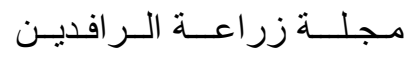

Vol. (48) No. (1) 2020

ISSN: 1815 - 316 X (Print)

المجلد (48) العدد (2) 2020

Taddeo, H. R. ; L. Duga ; P. Wellemas and S. Samlo (2000). Variation of mohair quality over the body in angora goats. Small Ruminant Research. 36(3): 285-291.

Von Bergen, W(1963). Handbook 3th.Ed.VI. John Willy and Sons Inc- New York, London.

Wyrostek, A ; S. Kinal and K. Czyz (2019). The influencing of zinc methionine bioplex supplementation to pregnant and lactating sheep on selected wool parameters. Archives Animal Breeding. 62(1): 99-105. 